PRZEGLĄD RUSYCYSTYCZNY 2021, nr 3 (175)

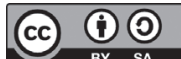

DOI 10.31261/pr.7505

\author{
JOANNA OLECHNO-WASILUK \\ Uniwersytet Warmińsko Mazurski, Olsztyn \\ iD ORCID http://orcid.org/0000-0002-7500-5151
}

\title{
RAMA INTERPRETACYJNA W DEFINICJI LEKSYKOGRAFICZNEJ
}

\section{AN INTERPRETATIVE FRAME IN A LEXICOGRAPHIC DEFINITION}

The paper is focused on analyzing a lexicographic definition in the Russian ideographic dictionary The world of man and the man in the surrounding world. Having in mind characteristics of a cognitive definition, the author undertakes an analysis of selected entries and investigates applying interpretative frames in the presented dictionary. The analyzed entries are juxtaposed with reactions to particular words-stimuli from the Russian Dictionary of Associations, and it is compared how an interpretative frame introduces order and organization into the knowledge on a given linguistic unit, that is the knowledge on a given fragment of the world surrounding the Russian people.

Keywords: interpretative frame, scripts, cognitive definition, lexicographic definition, Russian lexicography

We współczesnej leksykografii rosyjskiej obserwuje się odejście od nurtu lingwocentrycznego (lingwistykocentrycznego) i zwrot w kierunku podejścia antropocentrycznego ${ }^{1}$. Nowe stanowisko charakteryzuje się większą encyklopedycznością słowników lingwistycznych, w których zamieszczana jest informacja „ekstralingwistyczna” („pozajęzykowa"), niezbędna do odzwierciedlenia tła asocjacyjnego jednostki językowej koniecznego do pełnego jej zrozumienia. Definicje leksykograficzne zawierają informacje, które są znane przeciętnemu użytkownikowi języka: „описывают не то, что следует знать, а то, что реально знает практически любой социализированный представитель [...] национально-лингво-культурного со-

1 Zob. В.В. Морковкин, Антропоцентрический versus: лингвоцентрический подход клексикографированию, w: Национальная специфика языка и ее отражение в нормативном словаре, Москва 1988, s. 131-136. 
общества [...]”2. Galina Sklariewskaja podkreśla, że słowniki antropocentryczne opisują żywy język: „они описывают не абстрактную систему, а живой язык, данный в реальном употреблении и ориентированный на языковое сознание современников"з.

O konieczności antropocentrycznego podejścia w objaśnianiu znaczenia mówiła pod koniec lat 90. minionego wieku Anna Wierzbicka. Badaczka rozumiała znaczenie słowa „jako coś, co ludzie myślą lub mają na myśli, gdy danego słowa używają"4. Ryszard Tokarski szuka w znaczeniu słów odniesień do kultury i wizji świata danego społeczeństwa. Do definicji znaczenia Wierzbickiej dodaje: „to coś, co ludzie mogą myśleć lub mogą mieć na myśli”’. Według Tokarskiego znaczenie to „pewien mentalny obraz obiektu, czynności, zdarzenia, cechy, itp. skorelowany na mocy konwencji językowej z danym słowem. Obraz ten warunkowany jest kulturowo, tzn. jest efektem przyjmowanych $\mathrm{w}$ danej społeczności językowej potrzeb poznawczych, pragnień i oczekiwań, postaw emocjonalnych i wartościujących [...]”6. Badacz mówi o otwartej definicji leksykograficznej, która „nie zamyka wszystkich możliwych interpretacji słowa w ostro zakreślonych i nieprzekraczalnych granicach" . Definicję odpowiadającą zapotrzebowaniom antropocentryzmu stworzył Jerzy Bartmiński i nazwał ją definicją kognitywną, która „uwzględnia zestaw wszystkich cech obiektu [...], jego nazwy w kulturze i w języku, zmierza do zbudowania językowego 'portretu' przedmiotu”" . Definicja ta przyjmuje za cel pełny opis typowego przedmiotu, budowany z punktu widzenia „naiwnego użytkownika języka”, co jest typowe dla podejścia antropocentrycznego. W leksykografii - na co zwracał uwagę Bart-

2 С.И. Брилева, Н.П. Вольская, Д.Б. Гудков, И.В. Захаренко, В.В. Красных, Русское культурное пространство: Лингвокультурологический словарь, Вып. первый, «Гнозис», Москва 2004, s. 9.

3 Г. Н Скляревская, Антропоцентрическая лексикография: идеи и практика, w: Лексикография. Язык. Речъ: сб. ст. памяти Анны Липовской, [bnw], София 2013, s. 95-104.

4 A. Wierzbicka, Język - umyst - kultura, Wydawnictwo Naukowe PWN, Warszawa 1999, s. 414.

5 R. Tokarski, Światy za stowami. Wykłady z semantyki leksykalnej, Wydawnictwo Uniwersytetu Marii Curie-Skłodowskiej, Lublin 2014, s. 220.

6 Tamże, s. 185.

7 R. Tokarski, Czy semantyka jest dyscyplina autonomiczna, „Linguistica Copernicana" 2013, nr 2 (10), s. 205.

8 J. Bartmiński, Językowe podstawy obrazu świata, Wydawnictwo Uniwersytetu Marii Curie-Skłodowskiej, Lublin 2007, s. 87.

9 J. Bartmiński, Lubelska etnolingwistyka, „Analecta” Rok XI, z. 1-2, 2002, s. 23. 
miński - nie ma sztywnej granicy między dwoma rodzajami wiedzy, tj. językową i pozajęzykową. W opinii badacza w przekazaniu elementów należących do tych dwóch przenikających się zasobów informacji pomocna jest definicja kognitywna. Za główny cel przyjmuje ona „zdanie sprawy” ze sposobu pojmowania przedmiotu przez mówiących danym językiem, tj. ze sposobu utrwalonej społecznie, i dającej się poznać poprzez język i użycie języka, wiedzy o świecie, kategoryzacji jego zjawisk, ich charakterystyki i wartościowania ${ }^{10}$. Bartmiński dodaje, że „to leksykograf powinien ustalić, jakie właściwości przedmiotu zostają w języku utrwalone, jakich aspektów przedmiotu dotyczą, jak te aspekty są wypełniane konkretnymi charakterystykami oraz jakie czynniki kulturowe wpływają na powstanie takiej właśnie struktury wyobrażenia przedmiotu" ${ }^{11}$. Wśród tych czynników uczony wyróżnia: wiedzę o świecie, typ racjonalności, system wartości, ale przede wszystkim podmiotowy punkt widzenia przedmiotu. Ujęcie przedmiotu $\mathrm{w}$ ten szczególny sposób Bartmiński określa mianem profilu.

Nie ulega wątpliwości, że w leksykografii podejście antropocentryczne przejawia się $\mathrm{w}$ tworzeniu nowych struktur definicji leksykograficznych i w poszukiwaniach optymalnej treści, która, według autorów, powinna być w nich zawarta. W wielu słownikach struktura definicji znacznie odbiega od tradycyjnej, znanej ze słowników objaśniających.

W artykule niniejszym analizie poddana zostanie definicja leksykograficzna $^{12}$ rosyjskiego słownika ideograficznego Мир человека и человек в окружающем его мире (80 концептов, относящихся к духовной, ментальной и материальной сферам жизни человека, daleј Мир человека и человек в окружающем его мире... (2011, red. Natalja Szwiedowa). Celem analizy jest zbadanie, jakie lingwistyczne założenia stały się podstawą teoretyczną do zbudowania nowej struktury definicji leksykograficznej. Ponieważ na podstawie wstępnego rozpoznania zauważamy podobieństwo struktury definicji do ramy interpretacyjnej, zbadamy, czy struktura artykułów hasłowych słownika opiera się na jej założeniach.

Koncepcja ramy interpretacyjnej sytuuje się w nurcie wczesnych kognitywnych badań nad semantyką języka i została zaproponowana

${ }^{10}$ J. Bartmiński, Językowe podstawy obrazu świata ..., s. 42.

${ }^{11}$ Tamże, s. 89.

${ }^{12}$ Terminu „definicja leksykograficzna” używać będziemy za J. Bartmińskim i R. Tokarskim i rozumieć będziemy go jako opis znaczenia w słowniku. 
przez Charlesa Fillmore’a, by „inaczej spojrzeć na język i możliwości jego opisu semantycznego" ${ }^{13}$.

Idea ramy (ang. frame, pierwotnie schemat szablonowy) wywodzi się z psychologii poznawczejit i stała się obiektem badań w naukach kognitywnych, związanych przede wszystkim ze studiami nad badaniami formy i funkcji ludzkiej pamięci. Na podstawie tych badań powstały trzy główne teorie naukowe: Teoria Systemu Schematów Marwina Minskiego w dziedzinie sztucznej inteligencji (1975), Lingwistyczna Teoria Ram Semantycznych Charlesa J. Fillmore'a (1973) oraz psychologiczna Teoria Perspektywy Daniela Kahnemana i Amosa Twierskogo (1984).

W lingwistyce mówi się o ramie między innymi w odniesieniu do roli wiedzy encyklopedycznej w procesie komunikacji. Fillmore, autor lingwistycznej teorii ram semantycznych, wykazywał pragmatyczne podejście do znaczenia słowa. Badacz przekonywał, że najważniejsze jest to, co należy wiedzieć, aby móc użyć danego słowa lub też rozumieć je, gdy używają je inni ${ }^{15}$.

Rama interpretacyjna to według Fillmore’a swoiste dla danego języka środki leksykalne i gramatyczne (kategorie leksykalne i gramatyczne) z przypisanymi im sensami, używane w odniesieniu do konkretnego zdarzenia, rzeczy czy jej właściwości. Ramę może tworzyć konkretne wypowiedzenie, ale „również [...] pojedyncze słowo jako element systemu leksykalnego. Rama to system pojęć powiązanych ze sobą w taki sposób, że rozumienie jednego z nich wiąże się z rozumieniem całości struktury, do której dany składnik pojęciowy należy $[\ldots] "$ "..16.

Marwin Minskij - amerykański naukowiec zajmujący się naukami kognitywnymi, badacz sztucznej inteligencji, autor publikacji przetłumaczonej na język rosyjski Фреймы для представления знаний (1979) - traktuje ramę jako sposób organizacji informacji przechowywanej w pamięci. Minskij przekonuje, że człowiek interpretuje

${ }^{13}$ R. Tokarski, Światy za stowami..., s. 207.

${ }^{14} \mathrm{Na}$ podstawie przeprowadzonych eksperymentów, w których badani powtarzali przedstawione im bajki, pochodzące z różnych kręgów kulturowych, stwierdzono, że każdy człowiek posiada w pamięci podświadomy wzór (schemat) typowej dla swojej kultury budowy i sposobu opowiadania historii. [...] dopasowuje on ją do kulturowo uwarunkowanego pamięciowego szablonu, często uwypuklając inne niż zasłyszane w niej elementy, zmieniając zakończenie lub przenosząc punkt kulminacyjny na inny moment [Pluwak 2009, 50].

15 Tamże.

${ }^{16}$ R. Tokarski, Światy za stowami..., s. 208. 
i poznaje otaczający go świat zawsze zgodnie z określonym schematem. By zrozumieć dany schemat, Minskij proponuje zastosowanie ramy pojmowanej jako zestaw pytań, które należy zadać, by w danej sytuacji się odnaleźć: „Aby zrozumieć działanie, o którym mowa lub, które dana osoba ma okazję obserwować, należy szukać odpowiedzi na takie pytania, jak: Jaki jest powód tego działania? Jaki jest cel działania? Jakie są konsekwencje tego działania? Na kogo (lub co) wpływa ta akcja? W jaki sposób jest to zrobione? ${ }^{17}$. Naukowcy podkreślają, że ilość zadawanych pytań może być różna, m.in. w zależności od sposobu mówienia danej osoby, jej stylu wypowiedzi.

$\mathrm{Z}$ pojęciem ramy interpretacyjnej związane jest pojęcie scenariusza, nazywanego przez Fillmore'a również sceną lub tłem motywacyjnym. Scenariusz to modele ludzkich doświadczeń i działań, obrazy przedmiotów, instytucji, relacji między nimi. Między ramą i scenariuszem istnieje obustronna zależność: rama uaktywnia scenariusz a scenariusz aktualizuje ramy w konkretnych tekstach.

Aby wyjaśnić zrozumienie sytuacji przedstawionej przez scenariusz uczeni Roger Schank i Robert Abelson, zaproponowali identyfikację scenariusza z najbardziej charakterystycznymi pytaniami zwykle związanymi z konkretną sytuacją. Uzyskanie odpowiedzi na te pytania pozwala zrozumieć daną scenę. Zasadniczo scenariusz ramowy $\mathrm{w}$ tym przypadku jest zbiorem pytań, które należy zadać w związku z pewną hipotetyczną sytuacją i sposobami odpowiedzi na nie $^{18}$. Taki schemat Nikołaj Bołdyriew również nazywa scenariuszem i rozumie go jako „ogół powtarzających się danych o różnych stereotypowych sytuacjach"19. Podobnie w tej kwestii wypowiadał się Jerzy Bartmiński: „zdania składające się na definicję słownikową zawsze odpowiadają na jakieś pytania, od rodzaju tych pytań zależy objaśnienie hasła" ${ }^{20}$.

W oparciu o koncepcję ramy Fillmore'a i Minskiego oraz scenariusza Schanka i Abelsona w niniejszych rozważaniach ramę inter-

${ }_{17}$ О.С. Полатовская, Фрейм-сценарий как тип концептов, „Вестник ИГЛУ” 2013, s. 161-166, https://cyberleninka.ru/article/v/freym-stsenariy-kak-tip-kontseptov (16.09.2018).

${ }_{18}$ Р. Шенк, Р. Абельсон, Скрипты, планы и знание, w: Труды 4 международной конференции по искусству, интеллекту, т. 6, «Кибернетика» АН СССР, Москва 1975, s. 208-220.

${ }^{19}$ Н.Н. Болдырев, Концепты и категории, их формирование и вербализация, w: Когнитивная семантика. Концептуализация и категоризация, Тамбов 2000, https://www.twirpx.com/file/926805/ (01.08.2018), s. 37.

${ }^{20}$ J. Bartmiński, Językowe podstawy obrazu świata..., s. 42. 
pretacyjną rozumieć będziemy jako zestaw pytań, które należy zadać, by daną sytuację (schemat) zrozumieć. „Kiedy opisujemy sytuację mówimy naszemu rozmówcy nie tylko, kto komu co zrobił, ale także kiedy, gdzie, jak i dlaczego to zrobil”"21. Jerzy Bartmiński nazywa takie pytania pytaniami „zwykłego, prostego człowieka”22.

Zmiana metod definiowania w stronę definicji kognitywnej (Bartmiński), otwartej (Tokarski) spowodowała znaczne wydłużenie definicji. Jednak, jak podkreśla Stanisława Niebrzegowska-Bartmińska, „specyfika definicji kognitywnej nie polega na jej większej długości [...], lecz przede wszystkim na przyjęciu innej, antropocentrycznej perspektywy oglądu świata" ${ }^{23}$. Wydłużenie definicji spowodowało również konieczność jej wewnętrznego uporządkowania. Anna Wierzbicka, na przykład, zaproponowała schematy definicyjne ${ }^{24}$.

W rosyjskim słowniku Мир человека и человек в окружающем его мире (8о концептов, относящихся к духовной, ментальной и материальной сферам жизни человека w celu uporządkowania definicji autorzy zastosowali zaimki: rzeczowne (kto, co), przymiotne (który, jaki), przysłowne (skąd, dokąd, gdzie, jak, kiedy). Stworzyli i wykorzystali konkretny schemat - 19 pytań z użyciem zaimków.

Wykorzystanie zaimków w strukturze definicji autorzy słownika tłumaczą tym, że deiktyczna (wskazująca) funkcja wyrazów zaimkowych jest ściśle powiązana z elementami sytuacji komunikacyjnej, co potwierdza przytoczoną wcześniej myśl, że opisując określoną sytuację, odpowiadamy na pytania: co, gdzie, kiedy, jak, dlaczego itd. Pytania te, zgodnie z terminowaniem „zestaw pytań, które należy zadać, by daną sytuację zrozumieć”, tworzą ramę interpretacyjną.

W omawianym słowniku hasło podzielone jest na 19 stref, każda z nich zaczyna się pytaniem typu: кто, что, какой, чей, как, сколько, насколько, который (среди подобного), где, куда, зачем, почемy itd. Po zaimku pytającym następuje odpowiedź a w dalszej części przytaczane są przysłowia i powiedzenia oraz fragmenty utworów

${ }^{21}$ С. В. Буренкова, Фрейм как способ моделирования фрагментов поля в идеографической лексикографии (на материале лексико-семантической группы «Неуклюжесть»), „Вопросы когнитивной лингвистики” 2009, nr 2 (019), S. 75 .

${ }^{22}$ J. Bartmiński, Językowe podstawy obrazu świata..., s. 27.

${ }^{23}$ S. Niebrzegowska-Bartmińska, O różnych wariantach definicji leksykograficznej - od taksonomii do kognitywizmu, „Etnolingwistyka” 2018 (30), s. 272. 259284.

${ }^{24}$ A. Wierzbicka, Język - umyst - kultura, Wydawnictwo Naukowe PWN, Warszawa 1999, s. 254-256. 
literackich obrazujące użycie opisywanej jednostki językowej. Materiałami źródłowymi analizowanego słownika są inne słowniki, np. Культурология. Краткий тематический словарь (2002), Энциклопедический словарь: А-Я (2002), Этимологический словарь русского языка (1973) oraz Narodowy Korpus Języka Rosyjskiego.

Pierwsza strefa hasła w badanym słowniku zaczyna się od pytań кто, что (pytania o przedmiot lub osobę, służące określeniu hasła), nр. лето - самое теплое время года, следующее за весной и предшествующее осени; время расцвета природы; кошка - домашнее животное семейства кошачьих, легко привыкающее к дому, охотник на домашних грызунов, самка такого животного [...], хищное млекопитающее [...]. Następne pytanie to какой (pytanie o atrybuty, cechy szczególne): лето - жаркое, знойное лето. Сухое, засушливое лето. Лето красное. Золотое лето. Дождливое, мокрое, прохладное лето. Урожайное, неурожайное лето. Летние грозы. Летние сорта яблок. Жаркое летнее солнце. Летний дождь. [...] Летние месяцы (июнь, июль, август); кошка - сукотная (беременная). Дикая, домашняя кошка. Дикий лесной кот. Дикая степная кошка. Породистые кошки. Пушистая кошечка. Белая, черная, серая [...]. Dalej pada pytanie o cechy typowe - каков: «Каково лето, таково сено»; Кошка умна, хитра. Кошка независима, горда, смела. Кошка осторожна, наблюдательна. [...]; Кошка независима, горда, смела. Кошка осторожна, наблюдательна. [...]. Kolejne pytanie to pytanie o przynależność do czegoś lub kogoś, o właściciela czegoś lub kogoś, o posiadacza jakiejś cechy - чей: Наше северное лето короткое. Ваше южное лето жаркое. Бабье лето. «Лето Господне» (произведение И. Шмелёва); кошка: Моя (твоя, его ...). Ничья кошка. Это наша общая кошка. Мамина кошка. Бабушкин кот. [...]. Как - to pytanie o sposób, stan, okoliczności: Лето пролетело незаметно. Солнце пригревает по-летнему. На улице тепло как летом. Одеться по-летнему легко, как летом, как в летнее время [...]; Мяукать, мурлыкать по-кошачьи, как кошка. [...]. Сколько - pytanie o ilość, częstotliwość, wielkość: Мы подружились за одно лето. Два (три) лета жил в деревне. Ни одного лета не жил в городе. Сколько лет, сколько зим! [...]; Известно около 120 пород домашних кошек и сотни их окрасов. Родилось пятеро котят. У нас в доме две кошки [...]. Насколько - pytanie o miarę, stopień, jakość; porównanie miar: Нынешнее лето холоднее прошлогоднего. Это лето гораздо теплее 
прошлого. На дворе совсем лето. [...]; Кошка менее дружелюбна, чем собака. Кошка - загадочнее всех домашних животных. Сиамская кошка скорее зверёк, чем домашнее животное. Привязанность к человеку у кошек сильнее, чем привычка к месту [...]. Который - pytanie o to, który z kolei: «Каким летом пошёл, таким не воротишься» (Даль); У каждой кошки свой характер. Каждая кошка особенна и интересна по-своему [...]. Где - pytanie o położenie, lokalizację, miejsce: Лето в городе. Провести лето в деревне. Здесь «Для каждой местности (широты) своё лето; у нас, в средней полосе, считают за лето: июнь, июль, август» (Даль). Обожествление кошки в Древнем Египте. Культ кошки на берегах Нила. Кошка дремлет на подоконнике на солнышке. Котята играют у печки. Кошки любят сидеть на плече хозяина [...]. Куда - pytanie o kierunek, ruch: В наши северные края лето ещё не пришло. [...]. Потерявшись, кошка обычно находит дорогу, приходит к своему дому [...]. Когда - pytanie o czas wydarzenia, sytuacji: За весной приходит лето. Позднее лето. К лету. Летом живем на даче. На лето уезжаем в деревню. Летние олимпийски игры. Летние каникулы [...]. Кошка живет рядом с человеком около пяти тысяч лет. Кошка скоро становится хозяйкой дома, занимая те места, которые ей понравились. Ночами кошка подкарауливает мышь [...]. Зачем - pytanie o cel, przeznaczenie: Одежда для лета. Летний домик. Накопить денег на отдых; Назначением домашней кошки было ловить мышей, не давать им разводиться в доме. Кошка и охотник и друг [...]. Почему - руtanie o przyczynę lub cel: Лето закончилось: пора уезжать с дачи. Из-за засушливого лета нет ни грибов, ни ягод; От бродячих кошек, от кошачьего мяуканья по ночам нет покоя. Невозможно спать: всю ночь под окнами «кошачий концерт» $[. . .]^{25}$.

Przytoczone przykłady potwierdzają, że definicje w omawianym słowniku zawierają elementy charakterystyczne dla wiedzy potocznej, czyli to, co kojarzy się przeciętnemu użytkownikowi języka rosyjskiego, na przykład z latem: ciepło, upał, żar z nieba, susza, wakacje, lato, które minęło. Powtarzają się takie cechy lata jak: gorące, ładne, upalne, suche, deszczowe, które przynależą do potocznej wiedzy o lecie. Zauważyć należy, że niektóre z tych opisów znajdziemy w rosyjskim

${ }^{25}$ Wybrane elementy artykułu hasłowego лето oraz кошка. Inne elementy definicji, które nie zostały uwzględnione w niniejszej analizie to: от - до (во времени); от - до (в пространстве); необходимость, должность, желаемость; действие, состояние, отнесённость; быть. 
słowniku asocjacyjnym Русский ассоциативный словарь. От стимула к реакции (daleј Русский ассоциативный словарь...). W jego definicjach również znajdujemy odpowiedzi na pytania (zadane przez jego twórców), na przykład: лето (какое?): жаркое 19; красное 10; теплое 7. Inne reakcje na słowo-bodziec lato to: жара 6; зима 4; осень, прошло, солнце 3; знойное, море, пляж, скоро, тепло, фрукты, холодное 2 [...]. Przytoczenie w niniejszych rozważaniach asocjacji ze wspomnianego opracowania jest w naszej opinii zasadne, gdyż „pozwalają one przeniknąc $\mathrm{w}$ [...] pamięć rodzimych użytkowników języka rosyjskiego i uzyskać odpowiedź na pytanie: „Jak myślą Rosjanie”26.

W słowniku Мuр человека и человек в окружающем его мире... za pomocą ramy interpretacyjnej (pytań) zrekonstruowano wiedzę o pewnym fragmencie otaczającego świata Rosjan. W słowniku tym informacja o haśle podana jest w sposób logiczny, w słowniku asocjacyjnym skojarzenia pojawiają się w sposób frekwencyjny. Reasumując, definicje w obu słownikach różnią się jedynie budową. Uwagę zwraca fakt, że odpowiedzi na zadane pytania ze słownika ideograficznego są tożsame z reakcjami na słowa-bodźce ze słownika asocjacyjnego. Dla porównania w słowniku Русский ассоциативный словарь odnotowano następujące reakcje na słowo-bodziec kotka: черная 11; собака 9; мышка 7; Мурка, серая, сиамская 5; мягкая, пушистая 4; дикая, домашняя, дохлая 2; [...]. Potwierdza to wcześniejszy wniosek, że definicje leksykograficzne w obu słownikach różnią się, ale ostatecznie odkrywają to samo. Definicja w słowniku Mup человека и человек в окружающем его мире... wpisuje się więc w metodologię definicji kognitywnej - powtarza skojarzenia, czyli wiedzę naiwnego użytkownika (logicznie opracowaną).

Powyższa analiza pozwala stwierdzić, że struktura definicji leksykograficznej w słowniku Мuр человека и человек в окружающем его мире... jest oparta na koncepcji ramy interpretacyjnej, chociaż $\mathrm{w}$ przedmowie do słownika autorzy nie powołują się na to pojęcie. Tworząc definicję zastosowali oni koncepcję stawiania pytań do hasła, podobnie jak Minskij w swoich założeniach o ramie interpretacyjnej. Zabieg wykorzystany przez autorów słownika pozwolił na stworzenie wspólnego schematu definicji leksykograficznej oraz na przekazanie wiedzy na temat opisywanej jednostki językowej w sposób uporządkowany i jednolity.

${ }^{26}$ Ю. Н. Караулов, Г. А. Черкасова, Н. В. Уфимцева, Ю. А. Сорокин, Е. Ф. Тарасов, Русский ассоциативный словарь. От стимула к реакции, РАН, АСТ, Астрель, Москва 2002, s. 3 (przeł. J.O.-W.). 


\section{REFERENCES}

Bartmiński, Jerzy. Językowe podstawy obrazu świata. Lublin: Wydawnictwo Uniwersytetu Marii Curie-Skłodowskiej, 2007.

Bartmiński, Jerzy. "Lubelska etnolingwistyka." Analecta 2002, Rok XI, z. 1-2. 21-22.

Boldyrev, Nikolay. "Kontsepty i kategorii, ikh formirovaniye i vebalizatsiya." Kognitivnaya semantika. Kontseptualizatsiya $i$ kategorizatsiya. 1 Aug. 2018 <https://www.twirpx.com/file/926805/> [Болдырев, Николай. “Концепты и категории, их формирование и вебализация". Когнитивная семантика. Концептуализация и категоризация. 1 Aug. 2018 <https://www.twirpx. com/file/926805/>].

Burenkova, Svetlana. "Freym kak sposob modelirovaniya fragmentov polya v ideograficheskoy leksikografii (na materiale leksiko-semanticheskoy gruppy «Neuklyuzhest'»)." Voprosy kognitivnoy lingvistiki 2009, № 2 (019): 73 -81 [Буренкова, Светлана. "Фрейм как способ моделирования фрагментов поля в идеографической лексикографии (на материале лексико-семантической группы «Неуклюжесть»)". Вопросы когнитивной лингвистики 2009, № 2 (019): $73-81$ ].

Dubichinskiy, Vladimir. Leksikografiya russkogo yazyka. Moskva: Nauka, Flinta, 2009 [Дубичинский, Владимир. Лексикография русского языка. Москва: Наука, Флинта, 2009].

Karaulov,Yuriy. Cherkasova, Galina. Ufimtseva, Natal'ya. Sorokin, Yuriy. Tarasov, Yevgeniy. Russkiy assotsiativnyy slovar'. V 2 t. Ot stimula k reaktsii. Moskva: AST, Astrel', 2002 [Караулов, Юрий. Черкасова, Галина. Уфимцева, Наталья. Сорокин, Юрий. Тарасов, Евгений. Русский ассоциативный словарь. В 2 т. От стимула к реакции. Москва: АСТ, Астрель, 2002].

Krysin, Leonid. "O 'Tolkovom slovare russkoy razgovornoy rechi'." Slovo i yazyk. Sbornik statey k 8o-letiyu akad. Yu.D. Apresyana. Moskva: Izdatel'stvo «Yazyki slavyanskikh kul'tur», 2011 [Крысин, Леонид. “О ‘Толковом словаре русской разговорной речи'.” Слово и язык. Сборник статей к 8о-летию акад. Ю.Д. Апресяна. Москва: Издательство «Языки славянских культур», 2011.

Minskiy, Marvin. Freymy dlya predstavleniya znaniy. Moskva: Izdatel'stvo Energiуa, 1979 [Минский, Марвин. Фреймы для представления знаний. Москва: Издательство Энергия, 1979. 18 July $2018<$ https://royallib.com/read/minskiy_marvin/freymi_dlya_predstavleniya_znaniy.html\#0 $>$.

Morkovkin, Valeriy. "Antropotsentricheskiy versus: lingvotsentricheskiy podkhod k leksikografirovaniyu." Natsional'naya spetsifika yazyka i yeye otrazheniye $v$ normativnom slovare. Moskva, 1988 [Морковкин, Валерий. "Антропоцентрический versus: лингвоцентрический подход к лексикографированию.” Национальная специфика языка и ее отражение в нормативном словаре. Москва, 1988].

Niebrzegowska-Bartmińska, Stanisława. "O różnych wariantach definicji leksykograficznej - od taksonomii do kognitywizmu.” Etnolingwistyka 2018, no. 30: 259-284.

Pluwak, Agnieszka. "Geneza i ewolucja pojęcia framing w naukach społecznych." Global Media Journal 2009, № 1(5): 49-79.

Shenk, Roger. Abel'son, Robert. "Skripty, plany i znaniye." Trudy 4 mezhdunarodnoy konferentsii poiskusstvu, intellektu, t. 6. Moskva: «Kibernetika» AN SSSR, 


\section{JOANNA OLECHNO-WASILUK}

1975 [Шенк, Роджер, Абельсон, Роберт. “Скрипты, планы и знание.” Труды 4 международной конференции по искусству, интеллекту, т. 6. Москва: «Кибернетика» АН СССР, 1975].

Shvedova, Nataliya (ed.). Russkiy ideograficheskiy slovar': Mir cheloveka i chelovek $v$ okruzhayushchem yego mire (8o kontseptov, otnosyashchikhsya k dukhovnoy, mental'noy i material'noy sferam zhizni cheloveka). Moskva: Institut russkogo yazyka im. V.V. Vinogradova, 2011 [Шведова, Наталия. Ed. Русский идеографический словарь: Мир человека и человек в окружающем его мире (8о концептов, относящихся к духовной, ментальной и материальной сферам жизни человека). Москва: Институт русского языка им. В. В. Виноградова, 2011].

Sklyarevskaya, Galina. “Antropotsentricheskaya leksikografiya: idei i praktika.” Leksikografiya. Yazyk. Rech': sb. st. pamyati Anny Lipouskoy. Sofiya, 2013 [Скляревская, Галина. “Антропоцентрическая лексикография: идеи и практика.” Лексикография. Язык. Речъ: сб. ст. памяти Анны Липовской. София, 2013].

Tokarski, Ryszard. Światy za stowami. Wykłady z semantyki leksykalnej. Lublin: Wydawnictwo Uniwersytetu Marii Curie-Skłodowskiej, 2014.

Tokarski, Ryszard. "Czy semantyka jest dyscypliną autonomiczną" Linguistica Copernicana 2013, no. 2 (10). 201-216.

Wierzbicka, Anna. Język - umyst - kultura. Warszawa: Wydawnictwo Naukowe PWN, 1999. 